\title{
Use of autoantibodies against tumor-associated antigens as serum biomarkers for primary screening of cervical cancer
}

\author{
Yingji Jin ${ }^{1}$, Seung Cheol Kim², Hyoung Jin Kim ${ }^{1}$, Woong Ju², Yun Hwan Kim ${ }^{2}$ and \\ Hong-Jin Kim ${ }^{1}$ \\ ${ }^{1}$ Laboratory of Virology, College of Pharmacy, Chung-Ang University, Dongjak-Gu, Seoul 06974, South Korea \\ ${ }^{2}$ Department of Obstetrics and Gynecology, Ewha Womans University College of Medicine, Yangcheon-Gu, Seoul 03760, \\ South Korea \\ Correspondence to: Hong-Jin Kim, email: hongjink@cau.ac.kr \\ Keywords: cervical cancer; autoantibody; tumor associated antigen; enzyme-linked immunosorbent assay; cervical intraepithelial \\ neoplasia \\ Received: June 14, $2017 \quad$ Accepted: October 02, $2017 \quad$ Published: November 01, 2017 \\ Copyright: Jin et al. This is an open-access article distributed under the terms of the Creative Commons Attribution License 3.0 \\ (CC BY 3.0), which permits unrestricted use, distribution, and reproduction in any medium, provided the original author and source \\ are credited.
}

\section{ABSTRACT}

Serum autoantibodies against tumor-associated antigens (TAAs) have received much attention as potential biomarkers for early detection of cancers, since they can be detected in the early stages of cancers. Autoantibodies against Cancer Antigen 15-3 (CA15-3), carcinoembryonic antigen (CEA), Cancer Antigen 19-9 (CA19-9), c-Myc, p53, heat shock protein (Hsp) 27 and Hsp70 have been suggested as potential markers for detecting several types of cancer. In the present study, the seven types of antibody listed above were evaluated for detecting cervical lesions. Enzymelinked immunosorbent assays (ELISAs) were used to measure IgG levels of the autoantibodies in women with normal cytology, cervical intraepithelial neoplasia (CIN) I, CIN II, CIN III and cervical cancer. The increases of anti-CA15-3 and antiCEA IgG in cervical cancer were more pronounced than the increases of the other markers, and the level of anti-CA19-9 IgG in CIN III stage was higher than in normal CIN I, CIN II or cervical cancer. A combination of ELISAs detecting anti-CA15-3, anti-CEA and anti-CA19-9 IgGs was found to reliably discriminate CINs from normal and to strongly differentiate cancer from normal $(90.3 \%$ of sensitivity and $82.1 \%$ of specificity). We suggest that the combination of three ELISA may be useful for detecting cervical lesions.

\section{INTRODUCTION}

Cervical cancer is the fourth most common cancer in women worldwide. GLOBOCAN estimates that 527,624 new cases were diagnosed as cervical cancer and 265,672 women died of it in 2012 [1]. Almost all cervical cancers are caused by infections with human papillomavirus (HPV) [2]. It is thought that invasive cervical cancer develops from a precancerous state termed cervical intraepithelial neoplasia (CIN) when infection with a highrisk HPV has persisted for 12-15 years [2]. CIN can be classified into CIN I, CIN II and CIN III according to the thickness of the layer of cervical epithelium containing abnormal cells [3]. Almost 90\% of CIN I (low grade CIN) cases regress within two years whereas $5 \%$ of CIN II and $40 \%$ of CIN III cases (CIN II and CIN III are classified as high grade CINs) develop into invasive cervical cancer [4-6]. The 5-year survival rate of cervical cancer reaches $90 \%$ when it is detected early and treated appropriately [7]. However, survival at the late stage is just $15-35 \%$ [8]. Therefore, early detection of cervical cancer is the key to increasing survival and requires an effective primary screening system.

The Papanicolaou test (Pap test) has been used as the primary screening test for cervical cancer for over five decades and has contributed to decreasing both morbidity 
Table 1: Clinicopathological characteristics of normal, CIN I, CIN II, CIN III and cancer groups

\begin{tabular}{|c|c|c|c|c|c|}
\hline & $\begin{array}{l}\text { Normal } \\
(n=28)\end{array}$ & $\begin{array}{l}\text { CIN I } \\
(n=28)\end{array}$ & $\begin{array}{l}\text { CIN II } \\
(n=30)\end{array}$ & $\begin{array}{l}\text { CIN III } \\
(n=31)\end{array}$ & $\begin{array}{l}\text { Cancer } \\
(n=31)\end{array}$ \\
\hline $\begin{array}{l}\text { Age, years } \\
(\text { Mean } \pm \text { SEM; } \\
\text { range) })^{\mathrm{a}}\end{array}$ & $\begin{array}{l}45.6 \pm 2.5 \\
(20-79)\end{array}$ & $\begin{array}{c}43.1 \pm 2.2 \\
(25-74)\end{array}$ & $\begin{array}{c}45.9 \pm 2.4 \\
(28-75)\end{array}$ & $\begin{array}{l}40.6 \pm 2.0 \\
(23-68)\end{array}$ & $\begin{array}{c}50.6 \pm 2.0 \\
(31-74)\end{array}$ \\
\hline $\begin{array}{l}\text { Histology of } \\
\text { cervical cancer } \\
\text { (Punch biopsy) }\end{array}$ & & & & & $\begin{array}{l}\text { Squamous cell carcinoma } \\
(\mathrm{n}=24 ; 77.4 \%) \\
\text { Adenocarcinoma } \\
(\mathrm{n}=6 ; 19.4 \%) \\
\text { Adenosquamous carcinoma } \\
(\mathrm{n}=1 ; 3.2 \%)\end{array}$ \\
\hline $\begin{array}{l}\text { Stage of } \\
\text { cervical cancer }\end{array}$ & & & & & $\begin{array}{c}\text { Ia }(n=7) \\
\text { Ib }(n=16) \\
\operatorname{IIb}(n=6) \\
\text { IVa }(n=1) \\
\text { IVb }(n=1)\end{array}$ \\
\hline
\end{tabular}

Differences between groups in age were analyzed using two-tailed Student's $t$-test.

${ }^{a}$ mean age of cancer group was higher than that of CIN I group or CIN III group (cancer vs CIN I, $p=0.016$; cancer vs CIN III, $p=0.0009)$.

${ }^{\mathrm{b}}$ classified by International Federation of Obstetrics and Gynecology (FIGO) clinical staging system.

and mortality $[9,10]$. However, its greatest drawback is its low sensitivity for detecting individuals at high risk of cervical cancer. It has been suggested that the sensitivity of a single Pap test for detecting CIN is only 51\%, which results in missing patients at high risk of cervical cancer [11]. Therefore, the American College of Obstetricians and Gynecologists (ACOG) has recently recommended combining the HPV DNA test with the Pap test [12]. The HPV DNA test has high sensitivity but low specificity [13]. Actually $50 \%$ of patients with cervical cancer in the United States never attended primary screening for cervical cancer [14]. Therefore, developing a simpler and more accurate primary screening system for cervical cancer is important for overcoming low participation in the screening program. Serology tests are usually considered to be the simplest and most non-invasive tests and have the advantages that they allow high throughput screening, samples are easy to collect and examination is cost-effective.

Many researchers have focused on serum autoantibodies as biomarkers for cancer diagnosis. Proteins related to autoantibody responses can undergo overexpression, mutation, degradation or changes in glycosylation during carcinogenesis [15, 16]. The resulting aberrant proteins can elicit immune responses and are usually termed tumor associated antigens (TAAs) [16], and the serum autoantibodies are considered potential biomarkers for early detection of cancers [16].

At the same time there are several arguments against using autoantibodies as biomarkers. First, elevated anti-TAA antibody levels are found in only $10-30 \%$ of cancer patients [17]. Second, autoantibodies are not only expressed and amplified in cancers but also in other diseases [16], and finally some can also be detected in healthy individuals [16]. Therefore, the use of autoantibodies in cancer screening has created confusion when attempted on its own [16]. Recently, however, combination assays for several types of anti-TAA antibodies have shown significantly improved sensitivities and specificities [16]. Therefore, using autoantibodies as biomarkers for detecting cancers remains an attractive possibility.

Changes in the levels of autoantibodies against Cancer Antigen 15-3 (CA15-3), carcinoembryonic antigen (CEA), c-Myc, p53, heat shock protein (Hsp)27 and Hsp70 have been found in several types of cancer [18-26]. In addition, elevated levels of Cancer Antigen 19-9 (CA19-9) have been observed in lung, gastric, breast and pancreatic cancers as well as cervical cancer [27-31]. However there have been few studies investigating antibody responses against TAAs in cervical cancer.

The present study focused on serum antibodies against the TAAs CA15-3, CEA, CA19-9, c-Myc, p53, Hsp27 and Hsp70, which are involved in invasion, metastasis, progression, transformation and death of cancer cells [32]. The levels of autoantibodies against these seven TAAs were evaluated in women with normal cytology, CIN I, CIN II, CIN III and invasive cervical cancer, and their profiles were compared with those reported in other cancers. 


\section{RESULTS}

\section{Clinicopathological characteristics of the normal, CIN I, CIN II, CIN III and cervical cancer groups}

The clinicopathological characteristics of the various cervical lesion groups are presented in Table 1. A total of 148 serum samples were collected, consisting of 28,28 , 30,31 and 31 sera from healthy women and women with, CIN I, CIN II, CIN III and cervical cancer, respectively, and the mean ages of the corresponding patients were $45.6,43.1,45.9,40.6$ and 50.6 years, respectively. The proportion of squamous cell carcinomas in the cancer group was $77.4 \%$, and that of adenocarcinomas was $19.4 \%$. These proportions are virtually identical to those found generally (squamous cell carcinoma: $80 \%$; adenocarcinoma: 20\%) [33].

\section{Levels of autoantibodies (IgG) against the seven TAAs in the various sera}

Enzyme-linked immunosorbent assays (ELISAs) were used to evaluate levels of circulating IgGs against the seven TAAs using the TAAs as coating antigens. The ELISA for detecting CA15-3 IgG is referred to here as ELISA-CA15-3, and similarly for the other ELISAs: ELISA-CEA; ELISA-CA19-9; ELISA-c-Myc; ELISA-p53; ELISA-Hsp27 and ELISA-Hsp70. The $\mathrm{R}^{2}$ values of mixtures of sera from controls and cancer patients exceeded 0.8 in the dilution range 1:6.25 to 1:400 for all seven ELISAs (Supplementary Figure 1), which therefore showed excellent linearity. Moreover, the interassay reproducibility of the ELISAs was found to be excellent (Supplementary Table 1).

The levels of circulating IgGs against the seven TAAs are shown in Figure 1. Anti-CA15-3 IgG and antiCEA IgG tended to increase with advancing stage of lesions (Figure 1A and 1B). Moreover, anti-CA15-3 IgG was significantly higher in the cancer group than in the normal and CIN I groups (Figure 1A). Similarly, anti-CEA IgG was significantly higher in the cancer group than in the normal, CIN I or CIN III group (Figure 1B). Unlike anti-CA15-3 and anti-CEA IgG levels, the anti-CA19-9 IgG level was only elevated in the CIN III group (Figure 1C). There were no significant differences between the various groups in terms of anti-c-Myc, anti-p53, antiHsp27 and anti-Hsp70 IgGs, all of which had slightly higher mean values in the cancer group than in the normal group (Figure 1D to $1 \mathrm{G}$ ). Analysis of the differences between groups by the Bonferroni correction indicated that the anti-CA15-3 IgG and anti-CEA IgG levels were critical parameters for differentiating cervical cancer, and the anti-CA19-9 IgG level was critical for differentiating CIN III (Table 2).
The frequencies of samples with elevated levels of autoantibodies (IgGs) against the seven types of TAA in the normal, CIN I, CIN II, CIN III and cervical cancer groups

The proportions of samples with elevated levels of IgGs against the seven types of TAAs (Table 3) were calculated based on the IgG levels in the ELISAs (Figure 1). Samples containing levels higher than the cut-off value $\left(95^{\text {th }}\right.$ percentile) of the normal group were regarded as seropositive (Table 3). Overall the frequencies of seropositives in the CINs and cervical cancer groups appeared to be below $20 \%$, indicating that many of their autoantibody levels overlapped with those in the normal group. Similar trends in autoantibody responses in patients with cancers have been reported previously $[21,23,25$, $34,35]$. The present results indicate that the frequencies of elevated anti-CA15-3, anti-CEA, anti-c-Myc, anti-p53 and anti-Hsp27 IgGs increase in cervical cancer, and those of anti-CEA and anti-CA19-9 IgG increase in the CIN III stage.

\section{Diagnostic performances of ELISA-CA15-3, ELISA-CEA, ELISA-CA19-9 and a combination of the three for discriminating the CIN I+, CIN II+, CIN III+ and cancer groups from the normal group}

The sensitivities, specificities, negative predictive values (NPV), positive predictive values (PPV) and accuracies of ELISA-CA15-3, ELISA-CEA, and ELISACA19-9 were calculated from the receiver operating characteristic (ROC) curves (Figure 2). The optimum cut-off values were obtained from the Youden's indexes of the ROC curves, which yield maximum values of sensitivity plus specificity, and the relevant diagnostic values were calculated based on these cut-off values. The three parameters (ELISA-CA 15-3, ELISA-CEA and ELISA-CA19-9) were combined by logistic regression. The individual assays had favorable sensitivities and specificities for discriminating $\mathrm{CIN}$ I+, CIN II+, CIN III+ and cancers from normal (Table 4). Importantly, all the area under the curve (AUC) values was elevated in the combination of ELISA-CA15-3, ELISA-CEA and ELISACA19-9 (Table 4). Moreover, the combination contributed to the increased sensitivity, specificity, NPV or PPV for discriminating $\mathrm{CIN} \mathrm{I+}$, CIN II+, CIN III+ and cancer from normal (Table 4).

Parallel and serial combinations of ELISACA15-3, ELISA-CEA and ELISA-CA19-9 were performed, and the sensitivities and specificities for discriminating $\mathrm{CIN} \mathrm{I}+$, CIN II+, CIN III + or cancer from normal are presented in Supplementary Table 2. The parallel combination increased sensitivity, whereas the serial combination did not. 
Table 2: Differences between groups in levels of IgGs against TAAs

\begin{tabular}{|c|c|c|c|c|c|c|c|c|}
\hline & & CA15-3 & CEA & CA19-9 & c-Мyc & P53 & Hsp27 & Hsp70 \\
\hline \multirow{2}{*}{ Normal vs. CIN I } & $P^{\mathrm{a}}$ & n.s. & n.s. & n.s. & n.s. & n.s. & n.s. & n.s. \\
\hline & $P^{\mathrm{b}}$ & n.s. & n.s. & n.s. & n.s. & n.s. & n.s. & n.s. \\
\hline \multirow{2}{*}{ Normal vs. CIN II } & $P^{\mathrm{a}}$ & 0.044 & 0.007 & n.s. & n.s. & n.s. & n.s. & n.s. \\
\hline & $P^{\mathrm{b}}$ & 0.308 & 0.049 & n.s. & n.s. & n.s. & n.s. & n.s. \\
\hline \multirow{2}{*}{ Normal vs. CIN III } & $P^{\mathrm{a}}$ & 0.010 & 0.046 & 0.004 & n.s. & n.s. & n.s. & n.s. \\
\hline & $P^{\mathrm{b}}$ & 0.07 & 0.322 & 0.028 & n.s. & n.s. & n.s. & n.s. \\
\hline \multirow{2}{*}{ Normal vs. Cancer } & $P^{\mathrm{a}}$ & 0.0001 & 0.0002 & n.s. & n.s. & n.s. & 0.030 & n.s. \\
\hline & $P^{\mathrm{b}}$ & 0.0007 & 0.0014 & n.s. & n.s. & n.s. & 0.210 & n.s. \\
\hline \multirow{2}{*}{ CIN I vs. CIN II } & $P^{\mathrm{a}}$ & n.s. & 0.046 & n.s. & n.s. & n.s. & n.s. & n.s. \\
\hline & $P^{\mathrm{b}}$ & n.s. & 0.322 & n.s. & n.s. & n.s. & n.s. & n.s. \\
\hline \multirow{2}{*}{ CIN I vs. CIN III } & $P^{\mathrm{a}}$ & n.s. & n.s. & 0.014 & n.s. & n.s. & n.s. & n.s. \\
\hline & $P^{\mathrm{b}}$ & n.s. & n.s. & 0.098 & n.s. & n.s. & n.s. & n.s. \\
\hline \multirow{2}{*}{ CIN I vs. Cancer } & $P^{\mathrm{a}}$ & 0.002 & 0.0005 & n.s. & 0.044 & n.s. & 0.046 & n.s. \\
\hline & $P^{\mathrm{b}}$ & 0.014 & 0.0035 & n.s. & 0.308 & n.s. & 0.322 & n.s. \\
\hline \multirow{2}{*}{ CIN II vs. CIN III } & $P^{\mathrm{a}}$ & n.s. & n.s. & 0.032 & n.s. & n.s. & n.s. & n.s. \\
\hline & $P^{\mathrm{b}}$ & n.s. & n.s. & 0.224 & n.s. & n.s. & n.s. & n.s. \\
\hline \multirow{2}{*}{ CIN II vs. Cancer } & $P^{\mathrm{a}}$ & 0.032 & n.s. & n.s. & n.s. & n.s. & n.s. & 0.042 \\
\hline & $P^{\mathrm{b}}$ & 0.224 & n.s. & n.s. & n.s. & n.s. & n.s. & 0.294 \\
\hline \multirow{2}{*}{ CIN III vs. Cancer } & $P^{\mathrm{a}}$ & n.s. & 0.004 & 0.033 & 0.046 & n.s. & 0.039 & n.s. \\
\hline & $P^{\mathrm{b}}$ & n.s. & 0.028 & 0.231 & 0.322 & n.s. & 0.273 & n.s. \\
\hline
\end{tabular}

Significant differences between groups are presented in bold.

${ }^{a} P$ value was calculated by Mann-Whitney- $U$ test.

${ }^{\mathrm{b}} P$ value was calculated by Bonferroni correction, and $P<0.05$ was considered as statistical significance.

n.s.: no significant difference.

The increases of anti-CA15-3 and anti-CEA IgG levels in cervical cancer were marked compared to the other autoantibodies (Table 2). Therefore, the diagnostic performances of the combination of ELISACA15-3 and ELISA-CEA were compared to those of the combination of ELISA-CA15-3, ELISA-CEA and ELISA-CA19-9 (Supplementary Table 3). The results indicated that the combination of the two parameters was adequate for improving diagnostic performance, but that the addition of ELISA-CA19-9 was useful for improving sensitivity, specificity, NPV, PPV and accuracy.

Taken together, these results indicate that the combination assay using three types of parameters reliably discriminates CINs from normal, and powerfully discriminates cancer from normal. Our results suggest that the combination assay could be useful for primary screening of cervical cancer.

\section{DISCUSSION}

\section{Suggested theories about autoantibody responses to TAAs}

TAAs are thought to acquire neo-antigenicities during the development of cancers [16]. However, it is not entirely clear why the TAAs, which are fundamentally autoantigens, stimulate immune responses. Some of the hypotheses that have been suggested are as follows. First, frequent tumor cell death due to apoptosis or necrosis can lead to aberrant modification of the proteins of cancer cells that allow them to stimulate the immune systems $[16,36]$. For instance, proteases released during tumor cell death can cause changes in the structural properties of the native epitopes of host proteins [16]. Second, some TAAs are inherently able to stimulate the immune system because their amino acid sequences and tertiary structures are similar to those 
A

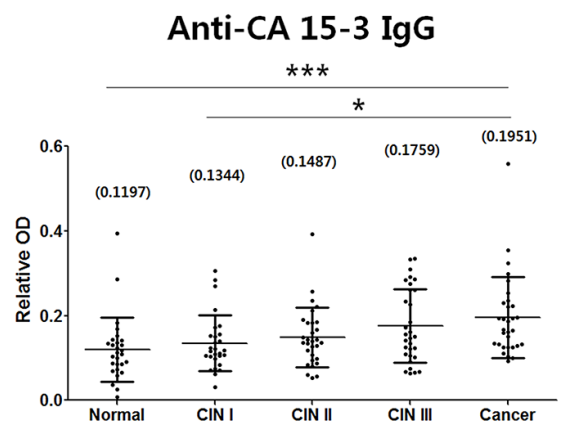

C

Anti-CA 19-9 IgG

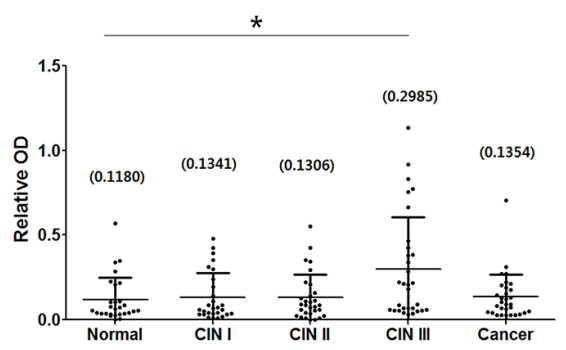

E

Anti-p53 IgG

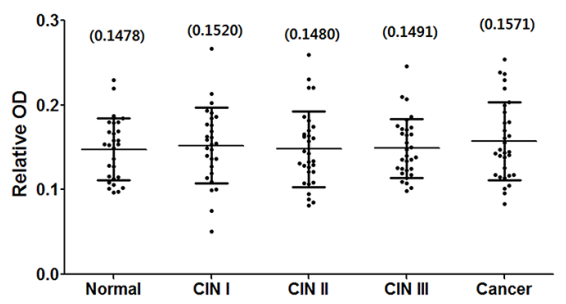

B

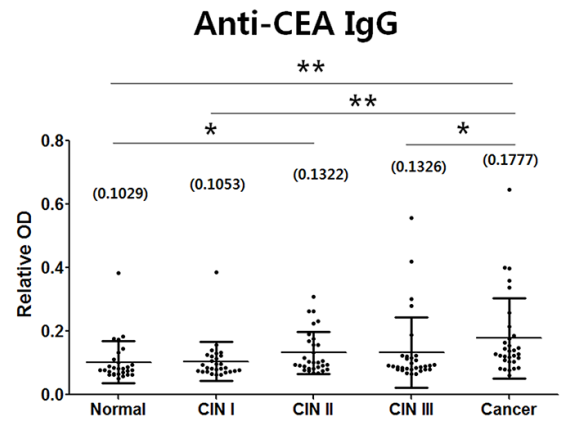

D

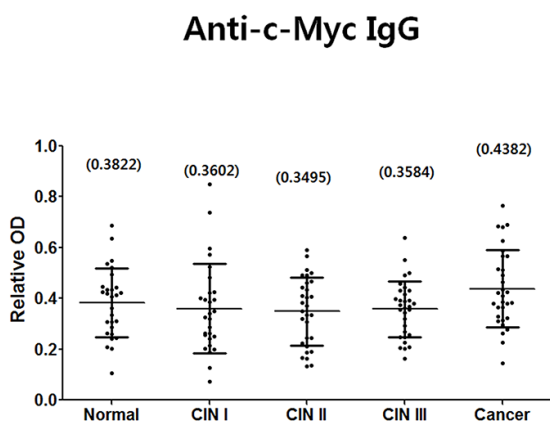

$\mathbf{F}$

\section{Anti-Hsp27 Ig G}

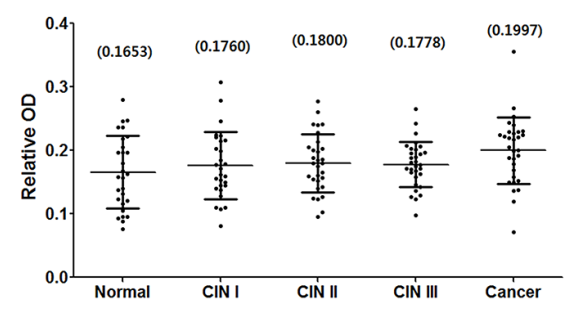

G

Anti-Hsp70 IgG

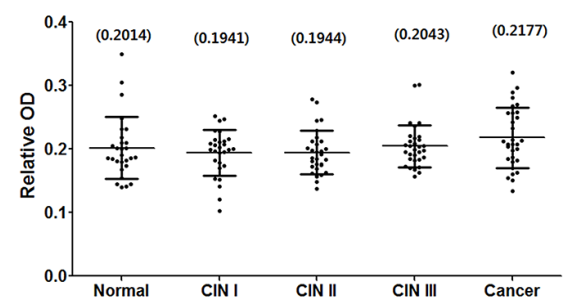

Figure 1: Comparison of IgG levels against CA15-3 (A), CEA (B), CA19-9 (C), c-Myc (D), p53 (E), Hsp27 (F) and Hsp70 (G) were measured in normal, CIN I, CIN II, CIN III and cancer groups. The procedure for detecting IgGs against relevant TAAs by ELISA is described in Materials and Methods. Central lines are mean values, and error bars show ranges of SD values. Normal, $n=28 ; C I N ~ I, n=28$; CIN II, $n=30$; CIN III, $n=31$; Cancer, $n=31$. Numbers in parenthesis are mean values. $P$-values were calculated from the Mann-Whitney-U test. The Bonferroni correction was performed, and $p<0.05$ was considered statistically significant $\left({ }^{*} p<0.05 ;{ }^{* *} p<0.01 ;{ }^{* * *} p<0.001\right)$. 
Table 3: Frequencies of autoantibodies against the CA15-3, CEA, CA19-9, c-Myc, p53, Hsp27 and Hsp70 TAAs in normal, CIN I, CIN II, CIN III and cancer groups

\begin{tabular}{lcccccccc}
\hline Group & N & $\begin{array}{c}\text { CA15-3 } \\
\mathbf{n}(\%)\end{array}$ & $\begin{array}{c}\text { CEA } \\
\mathbf{n}(\%)\end{array}$ & $\begin{array}{c}\text { CA19-9 } \\
\mathbf{n}(\%)\end{array}$ & $\begin{array}{c}\text { c-Myc } \\
\mathbf{n}(\%)\end{array}$ & $\begin{array}{c}\text { p53 } \\
\mathbf{n}(\%)\end{array}$ & $\begin{array}{c}\text { Hsp27 } \\
\mathbf{n}(\%)\end{array}$ & $\begin{array}{c}\text { Hsp70 } \\
\mathbf{n}(\%)\end{array}$ \\
\hline Normal & 28 & $1(3.6 \%)$ & $1(3.6 \%)$ & $1(3.6 \%)$ & $1(3.6 \%)$ & $1(3.6 \%)$ & $1(3.6 \%)$ & $1(3.6 \%)$ \\
CIN I & 28 & $0(0 \%)$ & $1(3.6 \%)$ & $1(3.6 \%)$ & $2(7.1 \%)$ & $1(3.6 \%)$ & $2(7.1 \%)$ & $0(0 \%)$ \\
CIN II & 30 & $0(0 \%)$ & $1(3.3 \%)$ & $1(3.3 \%)$ & $0(0 \%)$ & $2(6.7 \%)$ & $1(3.3 \%)$ & $0(0 \%)$ \\
CIN III & 31 & $1(3.2 \%)$ & $3(9.7 \%)$ & $6(19.3 \%)$ & $0(0 \%)$ & $1(3.2 \%)$ & $1(3.2 \%)$ & $0(0 \%)$ \\
Cancer & 31 & $2(6.5 \%)$ & $5(16.3 \%)$ & $1(3.2 \%)$ & $4(12.9 \%)$ & $4(12.9 \%)$ & $2(6.5 \%)$ & $0(0 \%)$ \\
\hline
\end{tabular}

Cut-off value for each antibody was $95^{\text {th }}$ percentile of normal group. $P$ value was analyzed by the Fisher's exact test to compare differences between groups in the frequencies of the IgGs. $P<0.05$ was considered as significant difference. No significant differences were found between groups in the frequencies.

of foreign antigens [16]. Moreover, the autoantibodies play roles in homeostasis as well as in controlling disease stage [37], and numerous types of autoantibodies are involved in such roles. Also it seems that different autoantibody responses occur in different types of cancer [38]. Characterization of these various responses may well suggest new approaches to identifying cancers.

\section{Autoantibody responses against TAAs in various cancers}

Changes in the serum levels of anti-CA15-3, antiCEA, anti-CA19-9, anti-c-Myc, anti-p53, anti-Hsp27 and anti-Hsp70 IgG have been previously examined as potential markers of carcinogenesis [18-26, 39]. The frequencies of these autoantibodies in various cancers, including the present data, are compared in Table 5. Direct comparison of the antibody frequencies may be inappropriate because the studies used different cut-off values and statistical criteria. However, overall the frequencies of anti-CA15-3, antiCEA, anti-c-Myc, anti-p53 and anti-Hsp27 IgGs tended to increase in the cancers, but not those of anti-CA19-9 and Hsp70 IgG. Studies extending these findings to additional cancers are a high priority.

Importantly, anti-Hsp27 IgG tends to increase in cervical, ovarian and breast cancers whereas anti-Hsp70 IgG does not (Table 5). Hsps are highly conserved molecular chaperons with anti-apoptotic actions and roles in resistance to a variety of cellular stresses [40]. Expression of Hsp27, but not of Hsp70, has been reported to be inversely related to the histopathological grade of squamous cell carcinoma (oral and paraoral region) [41]. Antibody levels against Hsp27 and Hsp70 during cancer development deserve further study.

\section{Differences between serum TAA levels and IgG levels against TAAs}

Serum CA15-3, CEA, c-Myc, p53 and Hsp27 have been observed to increase in breast cancer, CA15-3 in colorectal cancers, p53 in lung cancer and colon cancer, and Hsp27 in ovarian cancer [42-52]. Consequently, serum IgG levels against the corresponding TAAs were found at elevated levels in many studies (Table 5) [18-23]. However, some discordant cases of antibody responses have been reported. For example a negative correlation was reported between serum CA19-9 level and antiCA19-9 IgG level (note: anti-SLeA IgG; CA19-9 is also known as SLeA [53]) in gastrointestinal cancer (Table 5) [39]. In ovarian cancer, one group found an elevated level of serum Hsp70 [54] while another detected no change in level of anti-Hsp70 IgG (Table 5) [25]. As mentioned, previous studies indicate that serum levels of CA15-3, CEA, CA19-9 and p53 increase in cervical cancer [31, 55-57] and we found that serum anti-CA15-3, anti-CEA and anti-p53 IgG levels increased while anti-CA19-9 IgG levels were unchanged (Table 5). Taken together, these findings indicate that increased levels of TAAs do not always guarantee corresponding increases in antibody responses.

\section{Antibody responses in cervical cancer probably involve cell surface TAAs}

It has been reported that the TAAs stimulating antibody responses in breast, lung and colorectal cancer frequently include intracellular proteins such as c-Myc, p53 and Hsps [16, 58-61]. However we found weak tendency for IgG autoantibodies against intracellular TAAs to increase in cervical lesions (Table 2 and 5) whereas responses against cell surface proteins such as the mucin type antigens (CA15-3, CA19-9) and CEA were strongly affected (Figure 1) [62-65]. Therefore it is thought that cell surface antigen-related immune responses are involved in cervical carcinogenesis. It has also been suggested that the elevated level of antibody against CA15-3 (MUC-1) promotes the survival of patients with early stage ovarian, gastric, lung, pancreatic and breast cancers [59]. Moreover, there are reports that a MUC-1based anti-cancer vaccine was effective against breast, 
colon and lung cancers: a vaccine made using MUC-1 as antigen elicited adaptive host immunity ( $\mathrm{B}$ or $\mathrm{T}$ cell response) targeting MUC-1-expressing cancer cells, and led to cancer cell death [66-68]. The effects of vaccines against mucin-type antigens on cervical cancer merit future study.

A

Normal vs. CIN I +

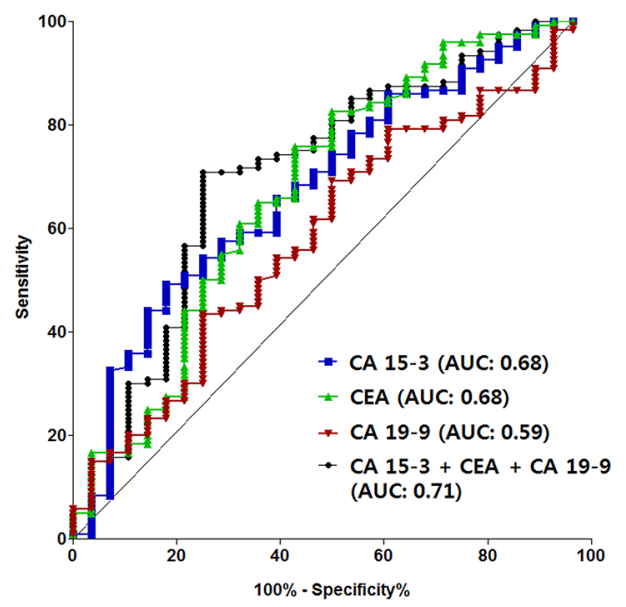

C Normal vs. CIN III +

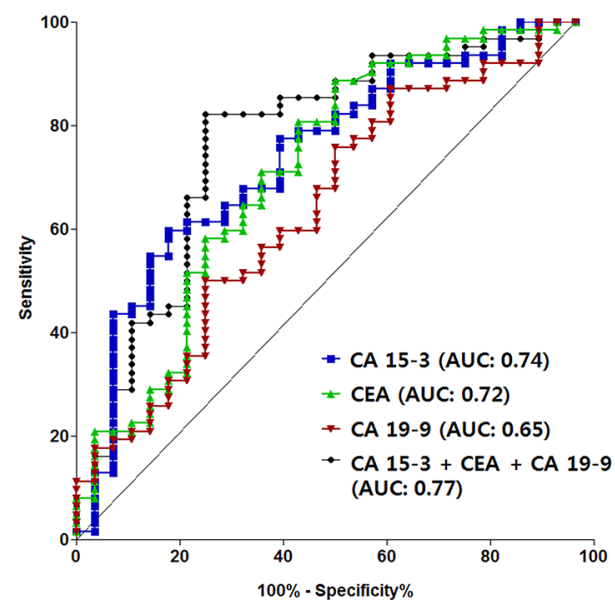

Changes in serum anti-CA19-9 IgG levels during cervical carcinogenesis

CA19-9 is an endothelial cell surface ligand for E-selectin that plays a major role in cancer cell adhesion, invasion and metastasis [53, 63]. Previously, it was reported

\section{B}

Normal vs. CIN II +

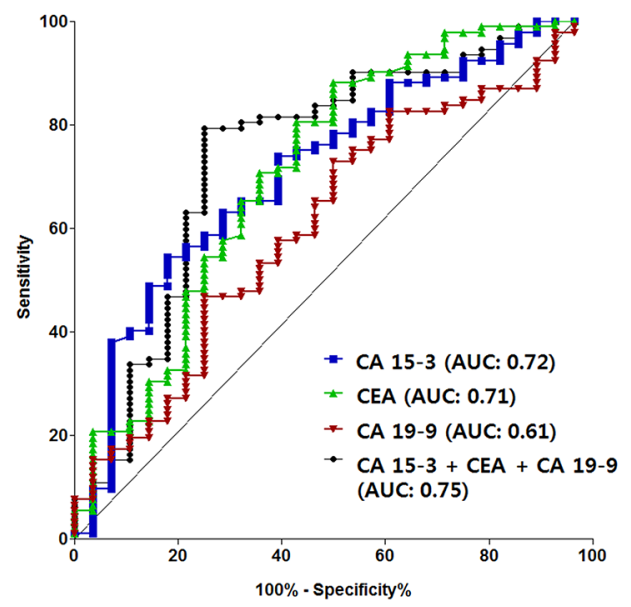

D Normal vs. Cancer

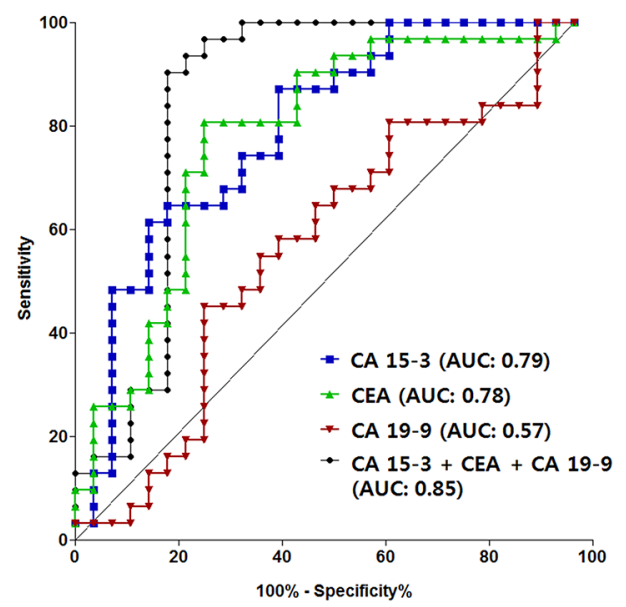

Figure 2: ROC curves for ELISA-CA15-3, ELISA-CEA, ELISA-CA19-9 and their combination for discriminating the CIN I+, CIN II+, CIN III+ and cancer groups from the normal group. ROC curves discriminating CIN I+ from normal (A), CIN II+ from normal (B), CIN III+ from normal (C), and cancer from normal (D). Blue, anti-CA15-3 IgG; green, anti-CEA IgG; red, anti-CA19-9; black, combination. 
Table 4: Diagnostic performances of ELISA-CA15-3, ELISA-CEA, ELISA-CA19-9 and combination assay of them for discriminating CIN I+, CIN II+, CIN III+ or cancer group from normal group

\begin{tabular}{|c|c|c|c|c|c|c|c|}
\hline Group & Marker & $\begin{array}{c}\text { AUC } \\
(95 \% \text { CI })\end{array}$ & Sensitivity & Specificity & NPV & PPV & Accuracy \\
\hline \multirow{4}{*}{$\begin{array}{l}\text { Normal } \\
\text { vs } \\
\text { CIN I+ }\end{array}$} & CA15-3 & $\begin{array}{c}0.68 \\
(0.56-0.78)\end{array}$ & $49.2 \%$ & $82.1 \%$ & $27.4 \%$ & $92.2 \%$ & $55.4 \%$ \\
\hline & CEA & $\begin{array}{c}0.68 \\
(0.54-0.78)\end{array}$ & $82.5 \%$ & $50.0 \%$ & $40.0 \%$ & $87.6 \%$ & $76.4 \%$ \\
\hline & CA19-9 & $\begin{array}{c}0.59 \\
(0.46-0.70)\end{array}$ & $69.2 \%$ & $50.0 \%$ & $27.5 \%$ & $85.6 \%$ & $50.0 \%$ \\
\hline & $\begin{array}{c}\text { Combination } \\
\text { CA15-3, } \\
\text { CEA and } \\
\text { CA19-9 }\end{array}$ & $\begin{array}{c}0.71 \\
(0.58-0.81)\end{array}$ & $70.8 \%$ & $75.0 \%$ & $37.5 \%$ & $92.4 \%$ & $71.6 \%$ \\
\hline \multirow{4}{*}{$\begin{array}{l}\text { Normal } \\
\text { vs } \\
\text { CIN II+ }\end{array}$} & CA15-3 & $\begin{array}{c}0.72 \\
(0.59-0.81)\end{array}$ & $54.4 \%$ & $82.1 \%$ & $35.4 \%$ & $90.9 \%$ & $60.8 \%$ \\
\hline & CEA & $\begin{array}{c}0.71 \\
(0.57-0.81)\end{array}$ & $88.0 \%$ & $50.0 \%$ & $56.0 \%$ & $85.3 \%$ & $79.2 \%$ \\
\hline & CA19-9 & $\begin{array}{c}0.61 \\
(0.48-0.72)\end{array}$ & $72.8 \%$ & $50.0 \%$ & $35.9 \%$ & $82.7 \%$ & $67.5 \%$ \\
\hline & $\begin{array}{c}\text { Combination } \\
\text { CA15-3, } \\
\text { CEA and } \\
\text { CA19-9 }\end{array}$ & $\begin{array}{c}0.75 \\
(0.61-0.84)\end{array}$ & $79.4 \%$ & $75.0 \%$ & $52.5 \%$ & $91.3 \%$ & $78.3 \%$ \\
\hline \multirow{4}{*}{$\begin{array}{l}\text { Normal } \\
\text { vs } \\
\text { CIN III+ }\end{array}$} & CA15-3 & $\begin{array}{c}0.74 \\
(0.61-0.84)\end{array}$ & $59.7 \%$ & $82.1 \%$ & $47.9 \%$ & $88.1 \%$ & $66.7 \%$ \\
\hline & CEA & $\begin{array}{c}0.72 \\
(0.57-0.82)\end{array}$ & $88.7 \%$ & $50.0 \%$ & $66.7 \%$ & $79.7 \%$ & $76.7 \%$ \\
\hline & CA19-9 & $\begin{array}{c}0.65 \\
(0.50-0.75)\end{array}$ & $87.1 \%$ & $39.3 \%$ & $57.9 \%$ & $76.1 \%$ & $72.2 \%$ \\
\hline & $\begin{array}{c}\text { Combination } \\
\text { CA15-3, } \\
\text { CEA and } \\
\text { CA19-9 }\end{array}$ & $\begin{array}{c}0.77 \\
(0.64-0.86)\end{array}$ & $82.3 \%$ & $75.0 \%$ & $65.6 \%$ & $87.9 \%$ & $80.0 \%$ \\
\hline \multirow{4}{*}{$\begin{array}{l}\text { Normal } \\
\text { vs } \\
\text { Cancer }\end{array}$} & CA15-3 & $\begin{array}{c}0.79 \\
(0.64-0.88)\end{array}$ & $61.3 \%$ & $85.7 \%$ & $66.7 \%$ & $82.6 \%$ & $72.9 \%$ \\
\hline & CEA & $\begin{array}{c}0.78 \\
(0.63-0.88)\end{array}$ & $80.7 \%$ & $75.0 \%$ & $77.8 \%$ & $78.1 \%$ & $78.0 \%$ \\
\hline & CA19-9 & $\begin{array}{c}0.57 \\
(0.40-0.70)\end{array}$ & $45.2 \%$ & $75.0 \%$ & $55.3 \%$ & $66.7 \%$ & $59.3 \%$ \\
\hline & $\begin{array}{c}\text { Combination } \\
\text { CA15-3, } \\
\text { CEA and } \\
\text { CA19-9 }\end{array}$ & $\begin{array}{c}0.85 \\
(0.68-0.93)\end{array}$ & $90.3 \%$ & $82.1 \%$ & $88.5 \%$ & $84.9 \%$ & $86.4 \%$ \\
\hline
\end{tabular}

Three types of parameters were combined by logistic regression. Sensitivity and specificity were evaluated based on Youden's index which yields maximum values of sensitivity plus specificity. NPV, negative predictive value; PPV, positive predictive value. 
Table 5: Frequencies of autoantibodies against CA15-3, CEA, CA19-9, c-Myc, p53, Hsp27 and Hsp70 TAAs in different types of cancers

\begin{tabular}{|c|c|c|c|c|c|c|c|c|}
\hline \multirow[t]{2}{*}{ TAA } & \multicolumn{2}{|c|}{$\begin{array}{c}\text { Frequency, \% } \\
\text { (number of IgG } \\
\text { positive/number of } \\
\text { tested) }\end{array}$} & \multirow[t]{2}{*}{ Cancer types } & \multirow[t]{2}{*}{ Antigen used } & \multirow{2}{*}{$\begin{array}{l}\text { Level change of } \\
\text { autoantibody } \\
\text { in cancer when } \\
\text { compared to } \\
\text { healthy control } \\
\text { (Statistical } \\
\text { significance) }\end{array}$} & \multirow[t]{2}{*}{$\begin{array}{l}\text { Power } \\
(1-\beta)^{b}\end{array}$} & \multirow[t]{2}{*}{$\begin{array}{l}\text { Cut-off } \\
\text { (Value of } \\
\text { normal } \\
\text { group) }\end{array}$} & \multirow[t]{2}{*}{ Reference } \\
\hline & $\begin{array}{l}\text { Normal } \\
\text { (Healthy } \\
\text { control) }\end{array}$ & Cancer & & & & & & \\
\hline \multirow{3}{*}{$\begin{array}{l}\text { CA15-3 } \\
\text { (Muc-1) }\end{array}$} & $\begin{array}{l}3.6 \% \\
(1 / 28)\end{array}$ & $\begin{array}{l}6.5 \% \\
(2 / 31)\end{array}$ & Cervical cancer & Native MUC 1 & Increased (n.s.) ${ }^{\mathrm{a}}$ & 0.94 & $\begin{array}{c}95^{\text {th }} \\
\text { percentile }\end{array}$ & Our study \\
\hline & $\begin{array}{l}23.2 \% \\
(13 / 56)\end{array}$ & $\begin{array}{c}32.8 \% \\
(40 / 122)\end{array}$ & Breast cancer & Recombinant MUC 1 & Increased (n.s.) & N/A & Mean+3SD & {$[18]$} \\
\hline & $\begin{array}{l}17.0 \% \\
(8 / 47)\end{array}$ & $\begin{array}{l}30.0 \% \\
(6 / 20)\end{array}$ & Colorectal cancer & $\begin{array}{l}\text { Synthetic peptide (five MUC1 } \\
\text { tandem repeats of the sequence } \\
\text { PDTRPAPGSTAPPAHGVTSA) }\end{array}$ & Increased (n.s.) & N/A & Mean+2SD & [19] \\
\hline \multirow{2}{*}{ CEA } & $\begin{array}{l}3.6 \% \\
(1 / 28)\end{array}$ & $\begin{array}{l}16.3 \% \\
(5 / 31)\end{array}$ & Cervical cancer & Native CEA & Increased (n.s.) $)^{a}$ & 0.86 & $\begin{array}{c}95^{\text {th }} \\
\text { percentile }\end{array}$ & Our study \\
\hline & $\begin{array}{l}7.1 \% \\
(2 / 28)\end{array}$ & $\begin{array}{l}28.9 \% \\
(15 / 52)\end{array}$ & Breast cancer & Native CEA & Increased $(p=0.025)$ & N/A & N/A & {$[20]$} \\
\hline \multirow{4}{*}{$\begin{array}{l}\text { CA19-9 } \\
\text { (SLeA) }\end{array}$} & $\begin{array}{l}3.6 \% \\
(1 / 28)\end{array}$ & $\begin{array}{l}3.2 \% \\
(1 / 31)\end{array}$ & Cervical cancer & Native CA19-9 & $\begin{array}{c}\text { No change } \\
\text { Increased only in } \\
\text { CIN III }(19.3 \% \text {; } \\
\text { n.s. })^{\mathrm{a}}\end{array}$ & $\begin{array}{c}\text { Cancer } \\
(0.12) \\
\text { CIN III } \\
(0.88)\end{array}$ & $\begin{array}{c}95^{\text {th }} \\
\text { percentile }\end{array}$ & Our study \\
\hline & $\begin{array}{l}6.2 \% \\
(\mathrm{~N} / \mathrm{A})\end{array}$ & $\begin{array}{l}8.6 \% \\
(\mathrm{~N} / \mathrm{A})\end{array}$ & $\begin{array}{l}\text { Gastrointestinal } \\
\text { cancer }\end{array}$ & CA19-9 conjugates with PAA & No change & N/A & N/A & [39] \\
\hline & $\begin{array}{l}6.2 \% \\
(\mathrm{~N} / \mathrm{A})\end{array}$ & $\begin{array}{c}0 \% \\
(\mathrm{~N} / \mathrm{A})\end{array}$ & Breast cancer & CA19-9 conjugates with PAA & No change & N/A & N/A & [39] \\
\hline & $\begin{array}{l}3.6 \% \\
(1 / 28)\end{array}$ & $\begin{array}{l}12.9 \% \\
(4 / 31)\end{array}$ & Cervical cancer & Recombinant c-Myc & Increased (n.s.) & 0.42 & $\begin{array}{c}95^{\text {th }} \\
\text { percentile }\end{array}$ & Our study \\
\hline \multirow{3}{*}{ c-Myc } & $\begin{array}{c}0 \% \\
(0 / 82)\end{array}$ & $\begin{array}{l}18.8 \% \\
(12 / 64)\end{array}$ & Breast cancer & Recombinant c-Myc & Increased $(p<0.001)$ & N/A & Mean+3SD & {$[21]$} \\
\hline & $\begin{array}{c}0 \% \\
(0 / 82)\end{array}$ & $\begin{array}{l}10.7 \% \\
(6 / 56)\end{array}$ & Lung cancer & Recombinant c-Myc & Increased $(p<0.001)$ & N/A & Mean+3SD & [21] \\
\hline & $\begin{array}{c}0 \% \\
(0 / 82)\end{array}$ & $\begin{array}{l}15.4 \% \\
(8 / 52)\end{array}$ & Gastric cancer & Recombinant c-Myc & Increased $(p<0.01)$ & N/A & Mean+3SD & [21] \\
\hline \multirow{5}{*}{ p53 } & $\begin{array}{l}3.6 \% \\
(1 / 28)\end{array}$ & $\begin{array}{l}12.9 \% \\
(4 / 31)\end{array}$ & Cervical cancer & Recombinant p53 & Increased (n.s.) & 0.21 & $\begin{array}{c}95^{\text {th }} \\
\text { percentile }\end{array}$ & Our study \\
\hline & $\begin{array}{l}1.3 \% \\
(1 / 76)\end{array}$ & $\begin{array}{c}26 \% \\
(48 / 182)\end{array}$ & Breast cancer & Recombinant $\mathrm{p} 53$ & $\begin{array}{l}\text { Increased } \\
(p=0.0001)\end{array}$ & N/A & $\begin{array}{l}2.5 \text { times of } \\
\text { Mean }\end{array}$ & {$[22]$} \\
\hline & $\begin{array}{l}1.2 \% \\
(2 / 82)\end{array}$ & $\begin{array}{l}9.6 \% \\
(5 / 52)\end{array}$ & Colon cancer & Recombinant $\mathrm{p} 53$ & Increased $(p<0.05)$ & N/A & Mean+3SD & {$[23]$} \\
\hline & $\begin{array}{c}8.3 \% \\
(10 / 120)\end{array}$ & $\begin{array}{l}41.7 \% \\
(25 / 60)\end{array}$ & Ovarian cancer & Recombinant $\mathrm{p} 53$ & $\begin{array}{l}\text { Increased } \\
(p<0.0001)\end{array}$ & N/A & Mean+2SD & {$[24]$} \\
\hline & $\begin{array}{l}2.4 \% \\
(2 / 82)\end{array}$ & $\begin{array}{l}16.1 \% \\
(9 / 56)\end{array}$ & Lung cancer & Recombinant p53 & Increased $(p<0.01)$ & N/A & Mean+3SD & [21] \\
\hline
\end{tabular}




\begin{tabular}{|c|c|c|c|c|c|c|c|c|}
\hline \multirow[t]{2}{*}{ TAA } & \multicolumn{2}{|c|}{$\begin{array}{c}\text { Frequency, \% } \\
\text { (number of IgG } \\
\text { positive/number of } \\
\text { tested) }\end{array}$} & \multirow[t]{2}{*}{ Cancer types } & \multirow[t]{2}{*}{ Antigen used } & \multirow[t]{2}{*}{$\begin{array}{l}\text { Level change of } \\
\text { autoantibody } \\
\text { in cancer when } \\
\text { compared to } \\
\text { healthy control } \\
\text { (Statistical } \\
\text { significance) }\end{array}$} & \multirow[t]{2}{*}{$\begin{array}{l}\text { Power } \\
(1-\beta)^{b}\end{array}$} & \multirow[t]{2}{*}{$\begin{array}{l}\text { Cut-off } \\
\text { (Value of } \\
\text { normal } \\
\text { group) }\end{array}$} & \multirow[t]{2}{*}{ Reference } \\
\hline & $\begin{array}{c}\text { Normal } \\
\text { (Healthy } \\
\text { control) }\end{array}$ & Cancer & & & & & & \\
\hline \multirow{3}{*}{ Hsp27 } & $\begin{array}{l}3.6 \% \\
(1 / 28)\end{array}$ & $\begin{array}{l}6.5 \% \\
(2 / 31)\end{array}$ & Cervical cancer & Recombinant Hsp27 & Increased (n.s.) & 0.75 & $\begin{array}{c}95^{\text {th }} \\
\text { percentile }\end{array}$ & Our study \\
\hline & $\begin{array}{l}3.4 \% \\
(1 / 29)\end{array}$ & $\begin{array}{l}50.0 \% \\
(17 / 34)\end{array}$ & $\begin{array}{c}\text { Ovarian } \\
\text { cancer }\end{array}$ & Recombinant Hsp27 & Increased (N/A) & N/A & Mean $+2 \mathrm{SD}$ & {$[25]$} \\
\hline & $\begin{array}{c}1.9 \% \\
(1 / 53)\end{array}$ & $\begin{array}{c}37.8 \% \\
(219 / 579)\end{array}$ & Breast cancer & N/A & Increased $(p<0.001)$ & N/A & N/A & {$[26]$} \\
\hline \multirow{4}{*}{ Hsp70 } & $\begin{array}{l}3.6 \% \\
(1 / 28)\end{array}$ & $\begin{array}{c}0 \% \\
(0 / 31)\end{array}$ & Cervical cancer & Recombinant Hsp70 & No change & 0.35 & $\begin{array}{c}95^{\text {th }} \\
\text { percentile }\end{array}$ & Our study \\
\hline & $\begin{array}{l}24.1 \% \\
(7 / 29)\end{array}$ & $\begin{array}{l}13.3 \% \\
(4 / 30)\end{array}$ & Ovarian cancer & Recombinant Hsp70 & No change & N/A & Mean $+2 \mathrm{SD}$ & {$[25]$} \\
\hline & $\begin{array}{l}24.1 \% \\
(7 / 29)\end{array}$ & $\begin{array}{l}32.4 \% \\
(11 / 34)\end{array}$ & $\begin{array}{l}\text { Endometrial } \\
\text { cancer }\end{array}$ & Recombinant Hsp70 & No change & N/A & Mean $+2 \mathrm{SD}$ & {$[25]$} \\
\hline & $\begin{array}{l}35.9 \% \\
(19 / 53)\end{array}$ & $\begin{array}{c}40.9 \% \\
(15 / 369)\end{array}$ & Breast cancer & N/A & No change & N/A & N/A & {$[26]$} \\
\hline
\end{tabular}

ELISAs were applied for all of the studies provided to detect relevant IgGs. n.s.: no significant difference; N/A: not available.

${ }^{a}$ Significant difference was found when analyzed by Mann-Whitney- $U$ test with Bonferroni correction.

that serum CA19-9 increased only in invasive cervical cancer not in the earlier CIN stages [31]. In our study, however, we found that serum anti-CA19-9 IgG was much higher in CIN III, than in the other groups (Table 2 and Figure 1C). About $40 \%$ of CIN III cases develop into invasive cervical cancer in contrast with only $1 \%$ of CIN I cases and $5 \%$ of CIN II cases [5]. The properties of CIN III cells resemble those of cancer cells and have a high potential for invasiveness [11]. Therefore it is likely that the elevated level of serum anti-CA19-9 IgG in CIN III impedes progression to cervical cancer through blocking the function of CA19-9 for the tissue invasion of cancerous cell. Since there is evidence that immunosuppression can occur during cancer development [69-72] it is possible that the drop in anti-CA19-9 IgG in cervical cancer itself is the result of immunosuppressive activity or of a requirement to increase the invasiveness of cancer cells.

\section{Use of an autoantibody panel to diagnose cancer}

The greatest drawback of autoantibodies against TAAs for cancer screening is their low sensitivity as individual autoantibodies. Researchers have tried to overcome this drawback by using autoantibody panels. Lung cancer was detected with $76 \%$ sensitivity and $92 \%$ specificity when seven autoantibodies (anti-c-Myc, -p53, -HER-2, -Muc-1, -NY-ESO-1, -CAGE and -GBU4-4 IgGs) were combined [73], and primary breast cancer was detected with $64 \%$ sensitivity and $85 \%$ specificity with a panel of seven autoantibodies (anti-p53, -c-Myc, -HER2, -NY-ESO-1, -BRCA1, -BRCA2 and -Muc-1 IgGs) [74]. Similarly colorectal cancer was detected with $60.9 \%$ sensitivity and $89.7 \%$ specificity with five autoantibodies (anti-p53, -p62, -c-Myc, -Imp1 and-Koc IgGs) [75].

In the present study, there were few samples with elevated autoantibody levels when cut-off values were set at the $95^{\text {th }}$ percentile of the normal group (Table 3). Serial combination of anti-CA15-3, anti-CEA and anti-CA19-9 ELISAs failed to improve sensitivity for discriminating CINs and cancer from the normal group, and parallel combination provided a limited improvement in sensitivity (Supplementary Table 2). Generally, both parallel and serial tests are carried out in combination assays. Each of them can in principle improve the sensitivity or the specificity of diagnosis, but neither can improve both parameters. Logistic regression can improve both sensitivity and specificity, and is based on the ROC curves obtained with the combination assay [76-80]. Indeed, satisfactory improvements in diagnostic performance were achieved in the present work when logistic regression was used (90.3\% sensitivity and $82.1 \%$ specificity for discriminating cervical cancer from normal, Table 4).

\section{Future direction for diagnosis using autoantibodies}

Numerous types of autoantibody candidates for diagnostic panels may exist in an embedded state. 
Therefore, the use of autoantibodies as biomarkers is likely to increase when high throughput screening systems can be used to detect novel candidates. Recently, several strategies have been developed for high throughput screening. Serological analysis of tumor antigens produced by recombinant cDNA expression cloning (SEREX), phage-display libraries, protein microarrays, serological proteome analysis (SERPA) and multiple affinity protein profiling (MAPPing) have all shown an increased ability to detect lung, breast, ovarian, prostate and liver cancers [16]. It is also likely that investigation of the expression patterns of IgG subclasses as well as of IgMs against TAAs will provide novel insights into autoantibody responses in cancers. In fact, Ann et.al. have reported that the pattern of expression of IgGs against MUC-1 in colorectal cancer differed from that of IgMs [19]. Such difference between IgGs and IgMs were also found in breast cancer [18].

In summary, based on previous reports and our results, the patterns of expression of autoantibodies against TAAs may be different according to the type of cancer and the stage of the lesions. Therefore, we expect that the accuracy of cancer diagnosis will be improved as knowledge of the profiles of antibodies to TAAs increases.

\section{MATERIALS AND METHODS}

\section{Ethics}

This study was conducted with the approval of the Institutional Review Board of EwhaWomans University Mokdong Hospital (approval No. EUMC 2016-07067-002). All of the human samples were collected in a prospective and consecutive manner with written informed consent.

\section{Specimens}

A total of 148 serum samples, or hysterectomy or cervical biopsy specimens were collected from women with normal cytology ( $n=28)$, CIN I ( $n=28)$, CIN II ( $n=30)$, CIN III $(n=31)$ and cervical cancer $(n=31)$. Each lesion was graded by three gynecology oncology specialists on the basis of review of hematoxylin and eosin (H\&E)stained sections cut from formalin-fixed and paraffinembedded tissue blocks. Individuals with negative results in the Pap smear test, and examination of H\&E-stained sections of hysterectomy specimens were classified as exhibiting normal cytology. Thus individuals in the "normal" group were those shown to have no abnormality in the cervix. Sera from the normal group were collected after examining hysterectomy specimens. Cervical cancer was graded according to the International Federation of Obstetrics and Gynecology (FIGO) staging system. Sera from the CIN I group were collected immediately after punch biopsy, and those from the CIN II and CIN III groups were collected before large loop excision of the transformation zone (LLETZ). Sera from cervical cancer patients were collected before surgery. The sera were collected from the median cubital, basilica or cephalic vein using a serum separation tube containing clot activator ( 8 $\mathrm{ml}$, Greiner Bio-One, Australia). A clotting time of $60 \mathrm{~min}$ was allowed, and the samples were centrifuged at 3,000 rpm for 15 to $20 \mathrm{~min}$. Finally, each serum was aliquoted into stock vials to avoid repeated freeze-thawing and stored at $-80^{\circ} \mathrm{C}$.

\section{Enzyme-linked immunosorbent assays (ELISAs)}

The following seven TAAs were used to detect circulating serum autoantibodies by ELISA: native CA15-3 (Fitzgerald, USA, \#30C-CP9064U), native CEA (Sigma, USA, \#C4835), native CA19-9 (Fitzgerald, USA, \#30-AC09), recombinant c-Myc (Fitzgerald, USA, \#30R-3138), recombinant GST-tagged p53 (Enzo, USA, \#BML-FW9370-0050), recombinant his-tagged Hsp27 (Fitzgerald, USA, \#80R-1231) and recombinant his-tagged Hsp70 (Fitzgerald, USA, \#80R-1011). 96well ELISA plates (Greiner bio-one, Australia) were coated overnight with TAAs [50 ng for ELISA-CEA, ELISA-c-Myc, ELISA-Hsp70 and ELISA-Hsp27; 100 ng for ELISA-p53; 6 units for ELISA-CA19-9; 12 units for ELISA-CA15-3] at $4^{\circ} \mathrm{C}$. The plates were blocked with 5\% skim milk (Bioworld, USA) in phosphatebuffered saline containing $0.05 \%$ Tween 20 (PBST) at room temperature (RT) for 2 hrs. Then serum samples were incubated in the wells at $37^{\circ} \mathrm{C}$ for $90 \mathrm{~min}$ at optimum dilution ratios [1:12.5 for ELISA-c-Myc and ELISA-Hsp27; 1:25 for ELISA-CA15-3, ELISACEA, ELISA-Hsp70 and ELISA-p53; 1:50 for ELISACA19-9]. The optimum serum dilution ratios above were based on the linear regions of the responses as a function of serum dilution (Supplementary Figure 1). All the sera were diluted with $0.5 \%$ skim milk in PBST. Circulating serum antibodies bound to the immobilized TAAs were detected using HRP-conjugated goat antihuman IgG antibody (Sigma, USA, \#A8667). The plates were washed three times with PBST between reactions, and five times prior to the reaction with substrate. Color reactions were developed using $o$-phenylenediamine (Sigma, USA), and measured at $492 \mathrm{~nm}$ using a FlexStation 3 Multi-Mode microplate reader (Molecular Devices, USA).

Data are presented in optical density (OD) units as employed previously $[18,20,21,23,25,81]$, with slight modifications. An ELISA omitting the antigen-coating step was performed to measure antibodies that react with the blocking agent (skim milk). The ODs of the seven types of ELISA were calculated from the equation: OD of ELISA with all reactants minus OD of ELISA omitting the antigen-coating step. 


\section{Statistical analysis}

Age differences between groups were analyzed by Student's t-test using Graphpad program version 5.01 (Graphpad software Inc, USA). The normality of distributions was evaluated with the Shapiro-Wilk test, and the Mann-Whitney-U test was used to evaluate differences in anti-TAA IgG levels between groups. Bonferroni corrections were performed for multiple comparisons, and $p<0.05$ was considered statistically significant. Differences between groups in the proportion of samples containing anti-TAA IgGs were analyzed by Fisher's exact test using Graphpad program version 5.01. Cut-off values for identifying seropositives were $95^{\text {th }}$ percentile of the normal group. The proportions of seropositives were calculated as: number of $\mathrm{IgG}$ positive samples/number of samples tested. Combination assays were analyzed by logistic regression using the free statistics and forecasting software, 'Bia-reduced logistic regression version 1-1.23-r7'(http:// www.wessa.net/). ROC curves and AUCs of individual or combination assays were calculated using Graphpad version 5.01 or NCSS statistical software (NCSS software, USA). The sensitivity, specificity, NPV, PPV and accuracy of each assay were determined from the ROC curves. The optimal cut-off values on the ROC curves were determined from Youden's Index which yields maximum values of sensitivity plus specificity. Power was analyzed with the G power 3.1 program (Franz Faul, Germany).

\section{Author contributions}

S.C.K, W.J, and Y.H.K collected serum samples and cervical biopsies. S.C.K, W.J, and Y.H.K graded cervical lesions. Y.J, H.J.K, and H-J.K conceived and designed the experiments. Y.J performed the experiments for ELISA. Y.J, H.J.K and H-J.K analyzed the data. Y.J and H.J.K wrote the paper. H-J.K is responsible for the integrity of the work as a whole. All the authors have accepted responsibility for the entire content of this submitted article and approved submission.

\section{ACKNOWLEDGMENTS AND FUNDING}

The present study was supported by Basic Science Research Program through the National Research Foundation of Korea (NRF) funded by the Ministry of Education (NRF-2015R1D1A1A01057370).

\section{CONFLICTS OF INTEREST}

The authors declared no conflicts of interest.

\section{REFERENCES}

1. Ferlay J, Soerjomataram I, Dikshit R, Eser S, Mathers C, Rebelo M, Parkin DM, Forman D, Bray F. Cancer incidence and mortality worldwide: sources, methods and major patterns in GLOBOCAN 2012. Int J Cancer. 2015; 136:E359-386.

2. Snijders PJ, Steenbergen RD, Heideman DA, Meijer CJ. HPV-mediated cervical carcinogenesis: concepts and clinical implications. J Pathol. 2006; 208:152-164.

3. Mishra GA, Pimple SA, Shastri SS. An overview of prevention and early detection of cervical cancers. Indian $\mathrm{J}$ Med Paediatr Oncol. 2011; 32:125-132.

4. Bosch FX, Burchell AN, Schiffman M, Giuliano AR, de Sanjose S, Bruni L, Tortolero-Luna G, Kjaer SK, Munoz N. Epidemiology and natural history of human papillomavirus infections and type-specific implications in cervical neoplasia. Vaccine. 2008; 26:K1-16.

5. Jastreboff AM, Cymet T. Role of the human papilloma virus in the development of cervical intraepithelial neoplasia and malignancy. Postgrad Med J. 2002; 78:225-228.

6. Peto J, Gilham C, Fletcher O, Matthews FE. The cervical cancer epidemic that screening has prevented in the UK. Lancet. 2004; 364:249-256.

7. Zampronha Rde A, Freitas-Junior R, Murta EF, Michelin MA, Barbaresco AA, Adad SJ, Oliveira AM, Rassi AB, Oton GJ. Human papillomavirus types 16 and 18 and the prognosis of patients with stage I cervical cancer. Clinics (Sao Paulo). 2013; 68:809-814.

8. Maranga IO, Hampson L, Oliver AW, Gamal A, Gichangi P, Opiyo A, Holland CM, Hampson IN. Analysis of factors contributing to the low survival of cervical cancer patients undergoing radiotherapy in Kenya. PLoS One. 2013; 8:e78411.

9. Runowicz CD. Molecular screening for cervical cancer--time to give up Pap tests? N Engl J Med. 2007; 357:1650-1653.

10. Suris JC, Dexeus S, Lopez-Marin L. Epidemiology of preinvasive lesions. Eur J Gynaecol Oncol. 1999; 20:302-305.

11. Litjens RJ, Hopman AH, van de Vijver KK, Ramaekers FC, Kruitwagen RF, Kruse AJ. Molecular biomarkers in cervical cancer diagnosis: a critical appraisal. Expert Opin Med Diagn. 2013; 7:365-377.

12. Committee on Practice Bulletins-Gynecology. ACOG Practice Bulletin Number 131: Screening for cervical cancer. Obstet Gynecol. 2012; 120:1222-1238.

13. Naucler P, Ryd W, Tornberg S, Strand A, Wadell G, Elfgren K, Radberg T, Strander B, Johansson B, Forslund O, Hansson BG, Rylander E, Dillner J. Human papillomavirus and Papanicolaou tests to screen for cervical cancer. N Engl J Med. 2007; 357:1589-1597.

14. Wong LP, Wong YL, Low WY, Khoo EM, Shuib R. Knowledge and awareness of cervical cancer and screening among Malaysian women who have never had a Pap smear: a qualitative study. Singapore Med J. 2009; 50:49-53.

15. Anderson KS, LaBaer J. The sentinel within: exploiting the immune system for cancer biomarkers. J Proteome Res. 2005; 4:1123-1133. 
16. Tan HT, Low J, Lim SG, Chung MC. Serum autoantibodies as biomarkers for early cancer detection. FEBS J. 2009; 276:6880-6904.

17. Casiano CA, Mediavilla-Varela M, Tan EM. Tumorassociated antigen arrays for the serological diagnosis of cancer. Mol Cell Proteomics. 2006; 5:1745-1759.

18. Tang Y, Wang L, Zhang P, Wei H, Gao R, Liu X, Yu Y. Detection of circulating anti-mucin 1 (MUC1) antibodies in breast tumor patients by indirect enzyme-linked immunosorbent assay using a recombinant MUC1 protein containing six tandem repeats and expressed in Escherichia coli. Clin Vaccine Immunol. 2010; 17:1903-1908.

19. Silk AW, Schoen RE, Potter DM, Finn OJ. Humoral immune response to abnormal MUC1 in subjects with colorectal adenoma and cancer. Mol Immunol. 2009; 47:52-56.

20. Haidopoulos D, Konstadoulakis MM, Antonakis PT, Alexiou DG, Manouras AM, Katsaragakis SM, Androulakis GF. Circulating anti-CEA antibodies in the sera of patients with breast cancer. Eur J Surg Oncol. 2000; 26:742-746.

21. Zhang JY, Casiano CA, Peng XX, Koziol JA, Chan EK, Tan EM. Enhancement of antibody detection in cancer using panel of recombinant tumor-associated antigens. Cancer Epidemiol Biomarkers Prev. 2003; 12:136-143.

22. Mudenda B, Green JA, Green B, Jenkins JR, Robertson L, Tarunina M, Leinster SJ. The relationship between serum p53 autoantibodies and characteristics of human breast cancer. Br J Cancer. 1994; 69:1115-1119.

23. Chen Y, Lin P, Qiu S, Peng XX, Looi K, Farquhar MG, Zhang JY. Autoantibodies to $\mathrm{Ca} 2+$ binding protein Calnuc is a potential marker in colon cancer detection. Int J Oncol. 2007; 30:1137-1144.

24. Anderson KS, Wong J, Vitonis A, Crum CP, Sluss PM, Labaer J, Cramer D. p53 autoantibodies as potential detection and prognostic biomarkers in serous ovarian cancer. Cancer Epidemiol Biomarkers Prev. 2010; 19:859-868.

25. Korneeva I, Bongiovanni AM, Girotra M, Caputo TA, Witkin SS. Serum antibodies to the $27-\mathrm{kd}$ heat shock protein in women with gynecologic cancers. Am J Obstet Gynecol. 2000; 183:18-21.

26. Conroy SE, Sasieni PD, Amin V, Wang DY, Smith P, Fentiman IS, Latchman DS. Antibodies to heat-shock protein 27 are associated with improved survival in patients with breast cancer. Br J Cancer. 1998; 77:1875-1879.

27. Berthiot G, Marechal F, Cattan A, Deltour G. Serum levels of CA-50, CA-19.9, CA-125, neuron specific enolase and carcinoembryonic antigen in lung cancer and benign diseases of the lung. Biomed Pharmacother. 1989; 43:613-620.

28. Victorzon M, Haglund C, Lundin J, Roberts PJ. A prognostic value of CA19-9 but not of CEA in patients with gastric cancer. Eur J Surg Oncol. 1995; 21:379-384.

29. Papantoniou V, Tsiouris S, Koutsikos J, Ptohis N, Lazaris D, Zerva C. Increased serum carbohydrate antigen 19-9 in relapsed ductal breast carcinoma. Hell J Nucl Med. 2006; 9:36-38.
30. Wu E, Zhou S, Bhat K, Ma Q. CA19-9 and pancreatic cancer. Clin Adv Hematol Oncol. 2013; 11:53-55.

31. Borras G, Molina R, Xercavins J, Ballesta A, Iglesias J. Tumor antigens CA 19.9, CA 125, and CEA in carcinoma of the uterine cervix. Gynecol Oncol. 1995; 57:205-211.

32. Bhatt AN, Mathur R, Farooque A, Verma A, Dwarakanath BS. Cancer biomarkers - current perspectives. Indian J Med Res. 2010; 132:129-149.

33. Lee MY, Shen MR. Epithelial-mesenchymal transition in cervical carcinoma. Am J Transl Res. 2012; 4:1-13.

34. Xu S, Huangfu M, Jia X, Song X, Sun B, Lee KH, Liu L, Sun S. FOXP3 autoantibody as a potential early prognostic serum biomarker in patients with cervical cancer. Int J Clin Oncol. 2015; 20:982-988.

35. Xu Y, Jin Y, Liu L, Zhang X, Chen Y, Wei J. Study of circulating IgG antibodies to peptide antigens derived from BIRC5 and MYC in cervical cancer. FEBS Open Bio. 2015; 5:198-201.

36. Utz PJ, Anderson P. Posttranslational protein modifications, apoptosis, and the bypass of tolerance to autoantigens. Arthritis Rheum. 1998; 41:1152-1160.

37. Poletaev A, Boura P. The immune system, natural autoantibodies and general homeostasis in health and disease. Hippokratia. 2011; 15:295-298.

38. Borghesi L, Milcarek C. From B cell to plasma cell: regulation of $\mathrm{V}(\mathrm{D}) \mathrm{J}$ recombination and antibody secretion. Immunol Res. 2006; 36:27-32.

39. Smorodin EP, Kurtenkov OA, Sergeyev BL, Lilleorg AL, Chuzmarov VI. Antibodies to tumor-associated carbohydrate epitopes in sera of cancer patients and blood donors. Experimental oncology. 2001; 23:109-113.

40. Franklin TB, Krueger-Naug AM, Clarke DB, Arrigo AP, Currie RW. The role of heat shock proteins Hsp70 and Hsp27 in cellular protection of the central nervous system. Int J Hyperthermia. 2005; 21:379-392.

41. Deyhimi P, Azmoudeh F. HSP27 and HSP70 expression in squamous cell carcinoma: An immunohistochemical study. Dent Res J (Isfahan). 2012; 9:162-166.

42. Lee JS, Park S, Park JM, Cho JH, Kim SI, Park BW. Elevated levels of preoperative CA15-3 and CEA serum levels have independently poor prognostic significance in breast cancer. Ann Oncol. 2013; 24:1225-1231.

43. Breuer B, De Vivo I, Luo JC, Smith S, Pincus MR, Tatum AH, Daucher J, Minick CR, Miller DG, Nowak EJ, Cody HS 3rd, Niman H, Carney WP, Brandt-Rauf PW. erbB-2 and myc oncoproteins in sera and tumors of breast cancer patients. Cancer Epidemiol Biomarkers Prev. 1994; 3:63-66.

44. Micelli G, Donadeo A, Quaranta M. The p53 tumor suppressor gene. A preliminary clinical study in breast cancer patients. Cell Biophys. 1992; 21:25-31.

45. Rui Z, Jian-Guo J, Yuan-Peng T, Hai P, Bing-Gen R. Use of serological proteomic methods to find biomarkers associated with breast cancer. Proteomics. 2003; 3:433-439. 
46. Barak V, Carlin D, Sulkes A, Treves A, Biran S. CA15-3 serum levels in breast cancer and other malignancies-correlation with clinical course. Isr J Med Sci. 1988; 24:623-627.

47. Luo JC, Neugut AI, Garbowski G, Forde KA, Treat M, Smith S, Carney WP, Brandt-Rauf PW. Levels of p53 antigen in the plasma of patients with adenomas and carcinomas of the colon. Cancer Lett. 1995; 91:235-240.

48. Luo JC, Zehab R, Anttila S, Ridanpaa M, HusgafvelPursiainen K, Vainio H, Carney W, De Vivo I, Milling C, Brandt-Rauf PW. Detection of serum p53 protein in lung cancer patients. J Occup Med. 1994; 36:155-160.

49. Greco C, Gandolfo GM, Mattei F, Gradilone A, Alvino S, Pastore LI, Casale V, Casole P, Grassi A, Cianciulli AM. Detection of C-myb genetic alterations and mutant p53 serum protein in patients with benign and malignant colon lesions. Anticancer Res. 1994; 14:1433-1440.

50. Fontanini G, Fiore L, Bigini D, Vignati S, Calvo S, Mussi A, Lucchi M, Angeletti C, Merlo G, Basolo F. Levels of p53 antigen in the serum of nonsmall cell lung-cancer patients correlate with positive p53 immunohistochemistry on tumor sections, tumor necrosis and nodal involvement. Int J Oncol. 1994; 5:553-558.

51. Langdon SP, Rabiasz GJ, Hirst GL, King RJ, Hawkins RA, Smyth JF, Miller WR. Expression of the heat shock protein HSP27 in human ovarian cancer. Clin Cancer Res. 1995; 1:1603-1609.

52. Zhao M, Shen F, Yin YX, Yang YY, Xiang DJ, Chen Q. Increased expression of heat shock protein 27 correlates with peritoneal metastasis in epithelial ovarian cancer. Reprod Sci. 2012; 19:748-753.

53. Ballehaninna UK, Chamberlain RS. Serum CA19-9 as a Biomarker for Pancreatic Cancer-A Comprehensive Review. Indian J Surg Oncol. 2011; 2:88-100.

54. Yousefi Z, Hasanzadeh Mofrad M, Kazemianfar Z, Ayatollahi H, Tavassoli F, Beyranvandi M, Aghayi MA. Comparison of serum levels of HSP70 and CA125 in patients with epithelial ovarian cancer and patients with benign ovarian masses. Iranian Journal of Obstetrics, Gynecology and Infertility. 2014; 17:1-5.

55. Benedetti Panici P, Scambia G, Baiocchi G, Sonsini C, Greggi S, Battaglia F, Mancuso S. Circulating tumor markers in cervical cancer. Tumour Biol. 1989; 10:109-116.

56. Ito $\mathrm{H}$, Kurihara $\mathrm{S}$, Nishimura C. Serum carcinoembryonic antigens in patients with carcinoma of the cervix. Obstet Gynecol. 1978; 51:468-471.

57. Sobti RC, Parashar K, Kaur R, Capalash N. Detection of human papillomavirus DNA, serum p53, and p53 antibodies in patients with cervical cancer. J Environ Pathol Toxicol Oncol. 2002; 21:79-85.

58. Piura E, Piura B. Autoantibodies to tumor-associated antigens in breast carcinoma. J Oncol. 2010; 2010:264926.

59. Reuschenbach M, von Knebel Doeberitz M, Wentzensen N. A systematic review of humoral immune responses against tumor antigens. Cancer Immunol Immunother. 2009; 58:1535-1544.

60. Desmetz C, Mange A, Maudelonde T, Solassol J. Autoantibody signatures: progress and perspectives for early cancer detection. J Cell Mol Med. 2011; 15:2013-2024.

61. Soussi T. p53 Antibodies in the sera of patients with various types of cancer: a review. Cancer Res. 2000; 60:1777-1788.

62. Misek DE, Kim EH. Protein biomarkers for the early detection of breast cancer. Int J Proteomics. 2011; 2011:343582.

63. Mann DV, Edwards R, Ho S, Lau WY, Glazer G. Elevated tumour marker CA19-9: clinical interpretation and influence of obstructive jaundice. Eur J Surg Oncol. 2000; 26:474-479.

64. Ringel J, Lohr M. The MUC gene family: their role in diagnosis and early detection of pancreatic cancer. Mol Cancer. 2003; 2:9.

65. Ghosh I, Bhattacharjee D, Das AK, Chakrabarti G, Dasgupta A, Dey SK. Diagnostic Role of Tumour Markers CEA, CA15-3, CA19-9 and CA125 in Lung Cancer. Indian J Clin Biochem. 2013; 28:24-29.

66. Gilewski T, Adluri S, Ragupathi G, Zhang S, Yao TJ, Panageas K, Moynahan M, Houghton A, Norton L, Livingston PO. Vaccination of high-risk breast cancer patients with mucin-1 (MUC1) keyhole limpet hemocyanin conjugate plus QS-21. Clin Cancer Res. 2000; 6:1693-1701.

67. Kimura T, McKolanis JR, Dzubinski LA, Islam K, Potter DM, Salazar AM, Schoen RE, Finn OJ. MUC1 vaccine for individuals with advanced adenoma of the colon: a cancer immunoprevention feasibility study. Cancer Prev Res (Phila). 2013; 6:18-26.

68. Sharma S, Srivastava MK, Harris-White M, Lee JM, Dubinett S. MUC1 peptide vaccine mediated antitumor activity in non-small cell lung cancer. Expert Opin Biol Ther. 2011; 11:987-990.

69. Shih NY, Lai HL, Chang GC, Lin HC, Wu YC, Liu JM, Liu KJ, Tseng SW. Anti-alpha-enolase autoantibodies are downregulated in advanced cancer patients. Jpn J Clin Oncol. 2010; 40:663-669.

70. Kusmartsev S, Gabrilovich DI. Role of immature myeloid cells in mechanisms of immune evasion in cancer. Cancer Immunol Immunother. 2006; 55:237-245.

71. Penn I, Starzl TE. Proceedings: The effect of immunosuppression on cancer. Proc Natl Cancer Conf. 1972; 7:425-436.

72. Zaenker P, Gray ES, Ziman MR. Autoantibody Production in Cancer--The Humoral Immune Response toward Autologous Antigens in Cancer Patients. Autoimmun Rev. 2016; 15:477-483.

73. Chapman CJ, Murray A, McElveen JE, Sahin U, Luxemburger U, Tureci O, Wiewrodt R, Barnes AC, Robertson JF. Autoantibodies in lung cancer: possibilities for early detection and subsequent cure. Thorax. 2008; 63:228-233. 
74. Chapman C, Murray A, Chakrabarti J, Thorpe A, Woolston C, Sahin U, Barnes A, Robertson J. Autoantibodies in breast cancer: their use as an aid to early diagnosis. Ann Oncol. 2007; 18:868-873.

75. Liu W, Wang P, Li Z, Xu W, Dai L, Wang K, Zhang J. Evaluation of tumour-associated antigen (TAA) miniarray in immunodiagnosis of colon cancer. Scand J Immunol. 2009; 69:57-63.

76. Schellekens DH, Hulsewe KW, van Acker BA, van Bijnen AA, de Jaegere TM, Sastrowijoto SH, Buurman WA, Derikx JP. Evaluation of the diagnostic accuracy of plasma markers for early diagnosis in patients suspected for acute appendicitis. Acad Emerg Med. 2013; 20:703-710.

77. Maeng YJ, Kim BR, Jung HI, Jung UW, Kim HE, Kim BI. Diagnostic accuracy of a combination of salivary hemoglobin levels, self-report questionnaires, and age in periodontitis screening. J Periodontal Implant Sci. 2016; 46:10-21.
78. Voigtlander T, Metzger J, Schonemeier B, Jager M, Mischak H, Manns MP, Lankisch TO. A combined bile and urine proteomic test for cholangiocarcinoma diagnosis in patients with biliary strictures of unknown origin. United European Gastroenterol J. 2017; 5:668-676.

79. Qian EN, Han SY, Ding SZ, Lv X. Expression and diagnostic value of CCT3 and IQGAP3 in hepatocellular carcinoma. Cancer Cell Int. 2016; 16:55.

80. Mihalyi A, Gevaert O, Kyama CM, Simsa P, Pochet N, De Smet F, De Moor B, Meuleman C, Billen J, Blanckaert N, Vodolazkaia A, Fulop V, D'Hooghe TM. Non-invasive diagnosis of endometriosis based on a combined analysis of six plasma biomarkers. Hum Reprod. 2010; 25:654-664.

81. Tong YQ, Liu B, Zheng HY, He YJ, Gu J, Li F, Li Y. BMI-1 autoantibody as a new potential biomarker for cervical carcinoma. PLoS One. 2011; 6:e27804. 